DOI: $10.22363 / 2312-9220-2021-26-4-705-712$

УДК 316.776 .4

Research article / Научная статья

\title{
Hypermedia and Recursive Mediatization of the Corporate News
}

\author{
Dmitrij I. Sharonov(c) \\ Lomonosov Moscow State University, \\ 27, bldg 4, Lomonosov Avenue, Moscow, 119234, Russian Federation \\ $\bowtie$ Dmitrij.Sharonov@gmail.com
}

\begin{abstract}
The article analyzes some trends in the dynamics of deep mediatization processes. The phenomenon of "saturation" of standard formats for presenting news with unexpected references, which transform the communication system, is revealed. For the correct interpretation of the discovered phenomena, the concept of "hypermedia" is used as an aspect of deep mediatization of the relationship between the company and its stakeholders. The model of recursive communication is concretized. The central point is the thesis about the self-applicability of the recursive method of studying the communication field. The influence of digital platforms algorithms on the daily practices of users has been investigated. The conclusions are formulated from an ecological point of view, highlighting the importance of creating an effective environment for corporate relations. The author believes that the transition to trans-disciplinary methods of researching the problems of deep mediatization in the digital era is inevitable. The role of philosophical reflection in determining the key areas of research is especially emphasized.
\end{abstract}

Keywords: deep mediatization, hypermedia, recursive communication, digital platforms, algorithms, corporate news, transdisciplinary methods

Conflicts of interest. The author declares that there is no conflict of interest.

Article history: submitted: May 15, 2021; accepted: June 1, 2021.

For citation: Sharonov, D.I. (2021). Hypermedia and recursive mediatization of the corporate news. RUDN Journal of Studies in Literature and Journalism, 26(4), 705-712. doi: 10.22363/2312-9220-2021-26-4-705-712 


\title{
Гипермедиа и рекурсивная медиатизация корпоративных новостей
}

\author{
Д.И. Шаронов \\ Московский государственный университет имени М.В. Ломоносова, \\ Российская Федерачия, 119234, Москва, Ломоносовский проспект, д. 27, корп. 4 \\ $\triangle$ Dmitrij.Sharonov@gmail.com
}

\begin{abstract}
Аннотация. В статье анализируются некоторые тенденции динамики процессов глубокой медиатизации. Выявлен феномен «насыщения» стандартных форматов подачи новостей неожиданными ссылками, трансформирующими систему коммуникации. Для корректной интерпретации обнаруженных явлений используется понятие «гипермедиа» как аспект глубокой медиатизации отношений между компанией и ее стейкхолдерами. Конкретизируется модель рекурсивной коммуникации. Центральным моментом является тезис о самоприменимости рекурсивного метода исследования коммуникационного поля. Исследовано влияние алгоритмов цифровых платформ на повседневные практики пользователей. Выводы сформулированы с экологической точки зрения, подчеркивая важность создания эффективной среды для корпоративных отношений. Автор считает неизбежным переход к трансдисциплинарным методам исследования проблем глубокой медиатизации в цифровую эпоху. Особо подчеркивается роль философской рефлексии в определении ключевых направлений исследований.
\end{abstract}

Ключевые слова: глубокая медиатизация, гипермедиа, рекурсивная коммуникация, цифровые платформы, алгоритмы, корпоративные новости, трансдисциплинарные методы

Заявление о конфликте интересов. Автор заявляет об отсутствии конфликта интересов.

История статьи: поступила в редакцию - 15 мая 2021 г.; принята к публикации - 1 июня 2021 г.

Для цитирования: Sharonov D.I. Hypermedia and recursive mediatization of the corporate news // Вестник Российского университета дружбы народов. Серия: Литературоведение. Журналистика. 2021. Т. 26. № 4. С. 705-712. doi: 10.22363/2312-9220-202126-4-705-712

\section{Introduction}

Against the backdrop of the COVID pandemic, the impact of media and technological change has highlighted some new trends in corporate communications strategies. Many companies had to move to a business model that worked entirely online. These challenges imply a senior management's willingness to face any unexpected turns in order to remain competitive. At the same time, researchers of mediatization processes pay comparatively less attention to this issue.

Mediatization has become an influential concept over the decade. It highlights the process of cultural changes that accompanies with the deep penetration 
of the media into various social domains. And more important - "many practices are now entangled with digital media, and the algorithms they are based on involve a new kind of recursivity. Human practice, when incorporating digital media and their infrastructures, leads to a continuous processing of data, which in turn is the basis for adapting these media" [1. P. 110].

Currently, digital ecosystem standards imply multilevel schemes of "organization", "configurations of configurations" by A. Hepp, and corporate business models are primarily based on the monetization of user data. On-demand search technology provides the digital platform with the ability to track the trajectory of a unique user and automatically rank his or her search results according to previously defined preferences. The world in its digital perspective seems to be compressed into complementary generic object types - data structures and algorithms that filter data streams. But how do the recursive properties of digital ecosystems transform corporate practices into ambivalent hyper modes?

There is a micro-segmentation effect known as an "echo chamber". The term "echo chamber" refers to a situation in which only certain ideas, beliefs, and sentiments are shared, such that those inside the echo chamber encounter only information they already agree with. The algorithms filter out incompatible information and create a bubble of like-minded resources [2]. Falling into a recursively closed circle of self-justified prophecies, media audiences are forced to delve into specific thematic priorities. But this is only one side of the issue. The opposite is the possibility of risky actor strategies to overcome domain boundaries and access wider communication spaces due to situational switching of network configurations. The recursive aspect of deep mediatization thus also includes special hyper - states of communication systems.

The purpose of this article is to propose a recursive model for interpreting corporate news. The familiar concept of "hypermedia" has been revisited as an analytical frame of reference, reflecting radical shifts in digital transformation processes.

These introductory remarks allow us to put forward hypothesis H1.: Reapplication of corporate agenda frames in ambiguous contexts is likely to lead to ad hoc switching of network domains, echoed by serious public resonance. RQ1: What is the essence and mechanics of these phenomena? RQ2: What transformations in the conceptual thesaurus of communication disciplines will require for their correct interpretation?

Methodology. This study systematized theoretical generalizations of the corporate agenda's over-saturation effect in ambivalent situations. Case study method has used.

\section{The Issue}

Following the example of Google, it is possible to reveal some strategies for deep mediatization of corporate news. The Google search engine occupies over $70 \%$ of the world market. Thus, on-demand search advertising is based on the 
ability to better understand what is most important to the target audience. In addition, the cost-per-click approach allows for much more accurate tracking of the relationship between the cost of an ad and its competitive advantage. Such services are sold only through an auction system governed by the rules of the digital platform. These guidelines are used to determine how Internet users interact with advertisers on a two-way marketplace that is technologically powered by Google Ads.

On March 30, 2021, Marshall Weil, Product Manager of the Privacy Sandbox project, posted a message about the start of a test period for the FLoK tracker, a new web technology Federated Learning of Cohorts. Google has raised some concerns. It was declared that many publishers rely on cookie-based advertising to support their content efforts. Cookie blocking was already spawning privacy-invasive workarounds (such as fingerprinting) that were even worse for user privacy. Google announced that blocking third-party cookies outright without viable alternatives for the ecosystem was irresponsible, and even harmful, to the free and open web [3].

The technically complex text is addressed exclusively to interested business and expert communities. But the scale of the subsequent resonance in the general public was incommensurate. The arguments put forward by the company and the declared practical intentions excited the entire advertising world and went far beyond the technical issue. Points of view ranged from incantations like "Google, please don't do this" to claims that we "have not seen so much craziness in the 10-plus years." Analytics markets were overheated, with some Google partners receiving triple-priced offers from agency holding companies, private equity funds and tech rollup firms around the world.

Partly the excessive reaction from business and the Internet community to the tech leader's initiative stems from the widespread adoption of his technology. Google Chrome is the internet's most popular web browser. But the diligence of the mainstream media in translating technical terms into everyday language is symptomatic. "The Economist" explains, that few people outside the advertising industry will mourn the death of third-party cookies. These are snippets of code placed on people's browsers that allow advertising companies to track them around the web, gather information about them and then flog products to them based on their interests. Google claims that semi-anonymity of FLoK technology is more protective of privacy than third-party cookies, which track specific users, but still $95 \%$ as effective at getting users to click on ads [4].

Instead of letting advertisers track the browsing history of individual users, as with cookies, FLoC groups similar online activities into numbered "cohorts", each containing thousands of such users. Semi-anonymity here means the hidden use of the so-called "dark patterns", about which the user is not informed and which he cannot turn off on his own. It may be difficult for Google to prevent people from grouping in a system according to characteristics they want to keep secret, such as race or sexual orientation. From a philosophical point of view, 
The Economist talks about the possible blurring of the border between the public and the private. Even a simple hint of such a possibility can alert any user.

Obviously, simply blocking third-party cookies will lead to new solutions from the ad technology industry. One of the ploy the Google is trying to prevent is fingerprinting. That's the generalized term for ways that websites can identify you through little data signals that leak out of your browser when you visit a site. Company has declared that FLoC is a lot better than the current status of thirdparty cookies that directly identify you anywhere you go on the web. But "better than the worst" is a low bar, and it's hard to know yet whether FLoC just clears it or vaults way over it, popular tech resource "The Verge" suggested [5].

Google has a long history of following the roadmap for implementing the new standard. Like most Internet applications today, FLoK is being developed openly and is part of a process of engagement other browser vendors. A detailed discussion always presupposes putting forward proposals, criticism, counterproposals and good faith efforts to make the Internet better as well. Back in January 2020, the company announced to the Internet community its determination to find generally acceptable options for ensuring the security of personal data. It was declared, that with continued iteration and feedback, privacy-preserving and openstandard mechanisms like the Privacy Sandbox can sustain a healthy, ad-supported web in a way that will render third-party cookies obsolete [6].

However, a year later it turned out that it was not possible to attract competitors to the project. Thus the statement of the testing period has become most important corporate news and innovation for the advertising domain. An avalanche of protests and negative comments on this issue was poured through the narrow professional framework, leaving behind only an unhealthy hype in the analytical services market. Similar examples of promotional behavior during the same period can be traced to other megabrands. All of these cases involve a common element - a positional statement of the company which contained an appeal to public opinion.

First, news of Bruce Springsteen's arrest for DUI did not surface until February 10th and as more details arose, the story became more confusing. Jeep said in the statement at the time they were right to suspend their Super Bowl ad until the fact is established. Springsteen's message of community and unity was more relevant than ever. Like the message that drunk driving can never be justified as well [7].

Volkswagen of America has announced that it will not change the name to the Voltswagen. The renaming was conceived as a Fool's Day announcement, highlighting the launch of the all-electric ID.4 SUV and signaling the company's commitment to providing electric mobility for all. There was also a promise to provide additional information on this matter [8]. But then only bewilderment and apologies followed.

Finally, Nike filed a lawsuit alleging that MSCHF was misusing Nike's trademarks. There is already, as it were, evidence of significant confusion and blurring in the marketplace, including calls for a boycott of Nike in response to 
the launch of MSCHF's Satan Shoes. Which was based on the erroneous assumption that Nike authorized or approved this product [9]. Thus the original media format, based on celebrity testimony, an outrageous fashion product (Satan's Shoes) or an awkward attempt to joke with the brand name (Voltsvagen), was radically switched and shifted towards noisy public debates.

The author insists that an adequate understanding of the sequence of these unusual cases involves the occupation of the superior meta-position of observation. Here public understanding of the of the company positioning is formed in a reflexive loop. The recursive circle, unfolding the media frames into a practical perspective, re-enter them into the very same figurations from which they were derived. "The news twisted the internet into knots" - one of the many commentators wrote. "What enter a reflexive loop are not physical stimuli, things, or messages as seen by an external observer, but challenges to or constraints on someone's understanding, - Klaus Krippendorff insisted. - I will call these 'objections' from the medium of a loop's embodiment. Objections say no' to someone's construction of reality when the expectations that derive from a construction are incommensurable with the experiences resulting from one's actions" [10. P. 83].

Similar to the operation of the "uncertainty principle" in modern physics, an attempt to test the threshold of ambivalent situations leads to spontaneous symmetry breaking. And the multiple echo reflections of public arenas recursively transformed the company's effective environment into a hyper-mode. The thirdparty publics raised the stakes and set disjunctive discursive agendas to alter defensive strategies used by corporate newsmakers.

\section{Discussion}

From widespread point of view mediatization means that other institutions are influenced by the working practices and preferences of the media, and that the media thus crucially shape the environment and operating conditions for other institutions [11]. This approach includes a distinction between several ideal types of media relations strategies: provision, promotion, and co-optation. Each line of work includes specific tasks and tools in different contexts of an unpredictable corporate environment. The rule of thumb for any corporation is economic rationality. But negative coverage of corporate matters can reduce profitability or cause reputational damage.

Designing and delivering media events at the right time and in the appropriate format is one of the key aspects of the corporate newsmaker's protective job [12]. We assume that these three strategies often work not sequentially, but in parallel, situationally shifting media frames towards more advantageous discursive positions. Hypermedia mode reverses the flow of corporate news through feedback loops within the communication circuit by roundabout ways. Then it becomes possible to connect different elements of recursive model through the effects of "switching" network domains. The dissimilar discursive "configurations of confi- 
gurations" build up in layers, constantly referencing each other. In all the cases considered above, the positional statements of the companies were calculated for additional public resonance and continuation of the discussion.

\section{Conclusion}

First of all, "imperative Internet usage complicates communication and exacerbates its non media effects and their assessment" [13. P. 89]. Uniting ties, configurations and narratives of heterogeneous domains into a single whole, the paradoxical effect of recursive mediatization requires its philosophical reflection. The concept expands fractally by referring to itself: deepening the process means formation of higher observation meta - positions. The hyper-dimensions of deep mediatization concept need further elaboration based on transdisciplinary empirical research as well.

Then, the problem requires more comprehensive review, including the recognition of media formats that provoke network domains switching. Practice shows that a new type of "hyperlinks", combining incompatible meanings, is really capable to transform corporate news strategies in uncertain situations. Corporate news agenda remains a significant indicator of change in the age of deep mediatization.

\section{References / Библиографический список}

[1] Hepp, A. (2020) Deep Mediatization. Routledge.

[2] Lachlan, K.A., Hutter, E., \& Gilbert, C. (2021). COVID-19 Echo Chambers: Examining the Impact of Conservative and Liberal News Sources on Risk Perception and Response. Retrieved May 10, 2021, from https://www.liebertpub.com/doi/10.1089/hs.2020.0176

[3] Vale, M. (2021). Privacy, Sustainability and the Importance of "And". Retrieved May 10, 2021, from https://blog.google/products/chrome/privacy-sustainability-and-theimpor tance-of-and/

[4] Why is FLoK, Google's new ad technology, taking flak. Retrieved May 10, 2021, from https://www.economist.com/the-economist-explains/2021/05/17/why-is-floc-googlesnew-ad-technology-taking-flak

[5] Bohn, D. (2021). Privacy and ads in Chrome are about to become flocing complicated. Retrieved May 10, 2021, from https://www.theverge.com/2021/3/30/22358287/privacyads-google-chrome-floc-cookies-cookiepocalypse-finger-printing

[6] Schuh, J. (2021). Building a more private web: A path toward making third party cookies obsolete. Retrieved May 10, 2021, from https://blog.chromium.org/2020/01/ building-more-private-web-path-towards.html

[7] Jeep Reinstates Bruce Springsteen's Super Bowl Ad After DUI Charge Is Dismissed. Retrieved May 10, 2021, from https://variety.com/2021/music/news/bruce-springsteenjeep-super-bowl-dui-1234914575/?cx_testId=49\&cx_testVariant=cx_1\&cx_artPos $=3 \#$ cxrecs_s

[8] Volkswagen of America said its name was changing. Now it admits it was just a disaster of an April Fool's stunt. Retrieved May 10, 2021, from https://edition.cnn.com/ 2021/03/30/business/volkswagen-voltswagen-update/index.html 
[9] Nike is Suing MSCHF for Trademark Infringement, Dilution Over "Satan Shoes". Retrieved May 10, 2021, from https://www.thefashionlaw.com/nike-is-suing-mschf-fortrademark-infringement-dilution-over-satan-shoes

[10] Krippendorff, K. (1994). "A Recursive Theory of Communication”. In D. Crowley, \& D. Mitchell (Eds.). Communication Theory Today (pp. 78-104). Cambridge UK: Polity Press.

[11] Ihlem, O., \& Pallas, J. (2014) Mediatization of Corporations. In Mediatization of Communication De Gruyter Mouton. Retrieved May 10, 2021, from https://www.resear chgate.net/publication/258973448_Mediatization_of_corporations

[12] Pallas, J., \& Fredriksson M. (2011). Providing, promoting and co-opting. Journal of Communication Management, 15(2), 165-178. DOI 10.1108/13632541111126373

[13] Shilina, M.G. (2020) Transformation of mediatization concepts in the context of the background COVID pandemic. Medialogiya kak sintez nauk. Jurnalistika. 88-93. (In Russ.)

Шилина М.Г. Трансформация концепций медиатизации в контексте фоновой COVID-пандемии // Медыялогія як сінтэз навук. Журналістыка. 2020. C. 88-93.

\section{Bio note:}

Dmitrij I. Sharonov, PhD in History of Philosophy, Associate Professor, Language and Communication Department, Faculty of Philosophy, Lomonosov Moscow State University. ORCID: 0000-0002-0919-1128; e-mail: Dmitrij.Sharonov@gmail.com

\section{Сведения об авторе:}

Шаронов Дмитрий Иванович, кандидат философских наук, доцент кафедры философии языка и коммуникации философского факультета МГУ имени М.В. Ломоносова. ORCID: 0000-0002-0919-1128; e-mail: Dmitrij.Sharonov@gmail.com 